\title{
ARBUSCULAR MYCORRHIZAL FUNGI COLONIZING THE PLANT COMMUNITIES IN ERITREA, NORTHEAST AFRICA
}

\author{
HARIKUMAR, V.S. ${ }^{1,4 *}$ - BlASZKOWSKI, J. ${ }^{2}$ - MEdHANIE, G. ${ }^{3}$ - KANAGARAJ, M.K. ${ }^{1}$ - DEEPAK \\ SAMUEL, V. ${ }^{1}$ \\ ${ }^{I}$ Department of Biology, Eritrean Institute of Technology, \\ Mai Nefhi, Eritrea, NE Africa \\ ${ }^{2}$ Department of Plant Protection, West Pomeranian University of Technology \\ Slowackiego 17, 71-434 Szczecin, Poland \\ ${ }^{3}$ Department of Biology, University of Asmara, \\ P.O. Box 1220, Asmara, Eritrea, NE Africa \\ ${ }^{4}$ Department of Post-Graduate Studies \& Research in Botany, Sanatana Dharma College \\ (University of Kerala), \\ Alappuzha-688003, Kerala, India \\ (phone: +910477 2269520, fax: +91 477 2266704) \\ *Corresponding author \\ e-mail:vsharikumar@gmail.com \\ (Received $15^{\text {th }}$ May 2013; accepted $14^{\text {th }}$ Aug 2014)
}

\begin{abstract}
The colonization and diversity of arbuscular mycorrhizal (AM) fungi associated with some common plants were investigated in Eritrea, northeast Africa. Of the 37 plant species belonging to 14 families collected, 26 were colonized by AM fungi. The mean percentage root length colonized was $21.34 \%$, ranging from $0-91 \%$. Nineteen plant species formed Paris-type and 10 Arum-type AM. The average spore density was 43 per $50 \mathrm{ml}$ air-dried soil and the average species richness was 2.4 AM species per sample. There was no correlation between percentage root length colonized by AM fungi, intensity of infection and spore density. Of the $21 \mathrm{AM}$ fungal taxa belonging to four genera isolated from the root region soils, two belonged to Archaeospora, two to Diversispora fifteen to Glomus and two to Scutellospora.
\end{abstract}

Key words: common plants; AM colonization; species diversity; Eritrea

\section{Introduction}

Arbuscular mycorrhizas (AM) fungi represent a monophyletic fungal lineage (Glomeromycota) that establishes an intimate association with most land plants of the universe. This symbiotic association is known to determine the function and biodiversity of the terrestrial ecosystems by producing extensive underground networks, composed of hyphae and spores; that interconnect a number of unrelated individual plant species (Bonfante and Genre, 2010). This symbiosis acts in important processes in the soil-plant interface, such as improving plant nutrition by increased nutrient and water uptake (Harley and Smith, 1983; Smith et al., 2011), enhancing establishment, growth and survival of seedlings through improved stress tolerance (Allen, 1991; Koske and Gemma, 1996; Giri et al., 2007); binding of sand grains into large aggregates (Tisdall and Oades, 1982); and improving soil structure that can influence plant succession (Koske, 1975).

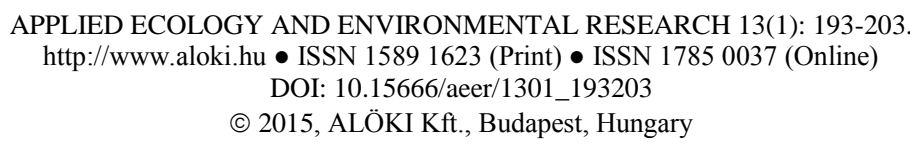


The fungal structures characteristic of AM colonization i.e. vesicles, arbuscules, hyphal coils and non-septate hyphae in the roots of plants, may have various functions related to both the fungus and the host (Smith and Smith, 1996, 1997). AM fungi develop two morphological types of colonization (Gallaud, 1905). These are: 1. the Arum-type, defined by intercellular hyphal growth in the root cortex; and 2. Paris-type, defined by cell-to-cell growth of intracellular hyphal coils (Smith and Smith, 1997). A prominent feature of the Arum-type morphology is the intercellular growth of hyphae in a longitudinal manner through the root. Arbuscules arise from the short side branches of these intercellular hyphae, typically at right angles to the main root axis (Smith and Smith, 1997). Coils of Paris-type mycorrhiza often, but not invariably become arbusculate i.e., they develop arbuscule branches from one or more loci on the coil (Gallaud, 1905; Smith and Read, 1997). The Arum-type morphology is abundant in field crops (Smith and Smith, 1997), whereas the Paris-type morphology has been more often seen in plants of natural ecosystems such as those occurring in herbaceous layers in temperate broad leaf forests (Brundrett and Kendrick, 1990) and plants of semi-arid systems (McGee, 1989).

Native plants play an important role in diversifying the land. Despite the low nutrient status, the sub-Saharan soils of Eritrea allow the growth of a number of native and exotic plant species which could act as hosts for AM fungi. However, this region is virgin as far as mycorrhiza research is concerned and even a preliminary study has not been conducted yet. The present study being the first, reports the incidence and diversity of AM fungi associated with some common plants of Eritrea.

\section{Materials and methods}

\section{Study site and sampling procedure}

The investigation was conducted in and around Asmara ( $15^{\circ} 28^{\prime}$, E $38^{\circ}$ 92'), Eritrea, located in the horn of Africa (Figure 1). The region is $2325 \mathrm{~m}$ above sea level and has an yearly average temperature of $16.89^{\circ} \mathrm{C}$ and precipitation of $519.5 \mathrm{~mm}$ measured by Department of Meteorology, Ministry of Civil Aviation, State of Eritrea. Thirty seven common plant species were collected in August (Summer) 2005 (Table 1) and identified according to Flora of Ethiopia and Eritrea (Edwards et al., 1995, 1997, 2000; Hedberg and Edwards, 1989, 1995; Hedberg et al., 2003). Roots were traced back to their point of emergence to ensure that they originally belonged to the plants selected for sampling. Roots from three replicates of each plant species were taken by pulling out the entire plant with utmost care to get the roots intact. The roots were gently tapped to remove the soil particles and the adherent debris, and pooled to get one composite sample, rinsed in tap water and processed in $50 \%$ ethanol.

Soil samples of ca $100 \mathrm{ml}$ were collected from the root region of replicate plant species to a depth of $20 \mathrm{~cm}$. One composite soil sample from each plant species was obtained by pooling the replicate samples. Soil samples were kept in fresh polythene bags, labeled and air-dried for $48 \mathrm{~h}$ at room temperature $\left(22^{\circ} \mathrm{C}\right)$ and ground to pass a 2$\mathrm{mm}$ sieve, stored at $4^{0} \mathrm{C}$ and processed within 2 months. A total of 37 soil samples were used in this study. 


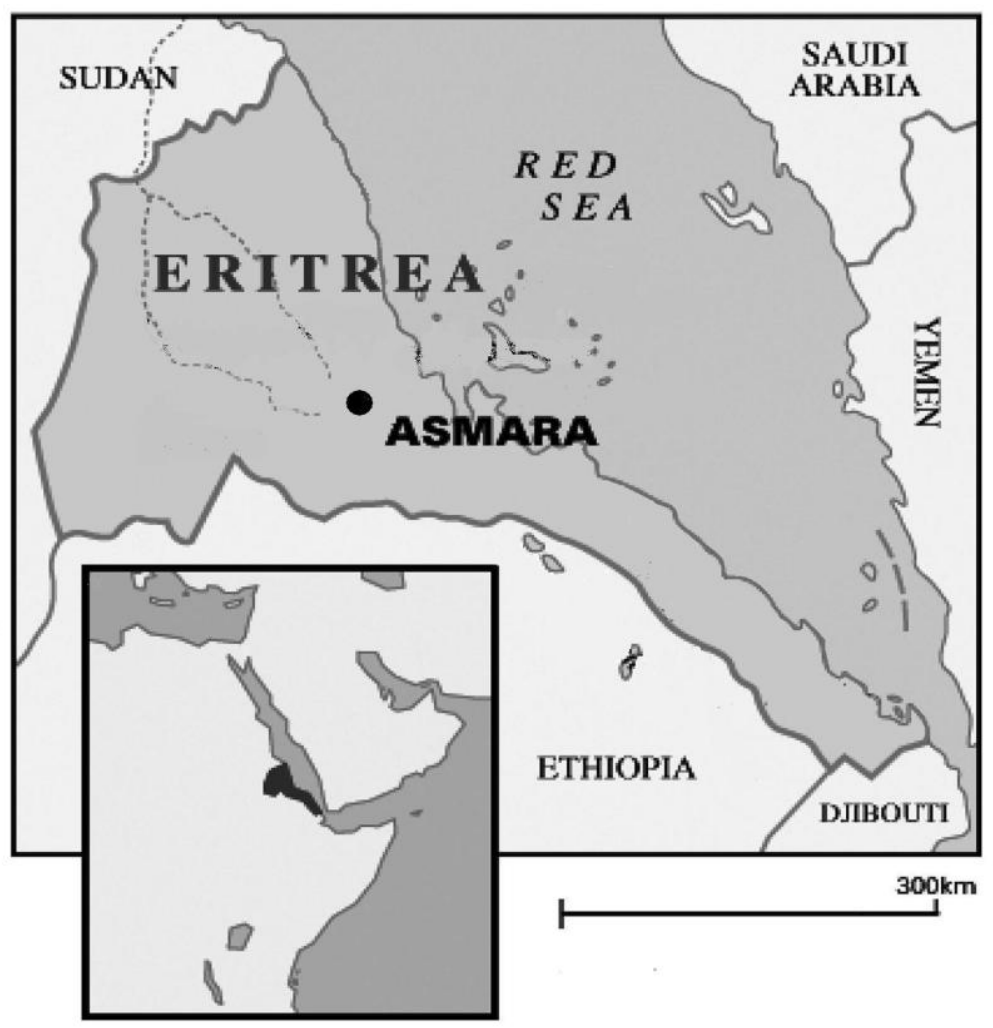

Figure 1. Map showing location of sample collection

\section{Root staining}

'Root samples were rinsed in tap water and stained with $0.05 \%$ cotton blue in acidic glycerol $(50 \%$ glycerol in $0.01 \% \mathrm{HCl})$ for $3 \mathrm{~min}$ at $121^{\circ} \mathrm{C}$ after tissue clearing in $2.5 \%$ $\mathrm{KOH}$ and bleaching in alkaline $\mathrm{H}_{2} \mathrm{O}_{2}\left(2 \% \mathrm{NH}_{4} \mathrm{OH}\right.$ in $\left.3 \% \mathrm{H}_{2} \mathrm{O}_{2}\right)$ as described by Koske and Gemma (1989) and examined with a compound microscope (Olympus BX50F4) at $\times 100-450$ for the presence of fungal structures. AM types were classified according to Smith and Smith (1997). The incidence of mycorrhizal colonization per sample was estimated as the percentage of root segments with hyphae, vesicles and arbuscules of AM fungi. Intensity of infection (\%) was calculated based on the abundance of hyphae, vesicles and arbuscules in each mycorrhizal root (Plenchette and Morel, 1996).

\section{Spore extraction and analysis}

Spores were isolated from $50 \mathrm{ml}$ air-dried soil taken from each composite sample by wet-sieving followed by floatation-centrifugation in 50\% sucrose (Dalpé, 1993). The finest sieve used was $45 \mu \mathrm{m}$. Spores were collected on a grid patterned $(4 \times 4)$ filter paper, washed three times with distilled water to spread them evenly over the entire grid and counted using a stereo microscope (Olympus SZX-ILLK200) at $\times 40$ magnification.

Healthy spores (based on shape, surface condition, spore contents and no evidence of parasitism) of each distinct morphotype (as distinguished by color, shape, and size) were directly counted. Morphological properties of spores and their wall structures were determined based on observation of at least 100 spores mounted in polyvinyl alcohol/lactic acid/glycerol (PVLG; Omar et al., 1979) and a mixture of PVLG and 
Melzer's reagent $(1: 1, \mathrm{v} / \mathrm{v})$. Spores were crushed to varying degrees by applying pressure to the cover slip and then stored at $65^{\circ} \mathrm{C}$ for $24 \mathrm{~h}$ to clear their contents from oil droplets. These were examined under a compound microscope (Olympus BX50F4) equipped with Nomarski differential interference contrast optics.

Terminology of the spore structures is as suggested by Stürmer and Morton (1997) and Walker (1983). Spore color was examined under a dissecting microscope on fresh specimens immersed in water. Color names are from Kornerup and Wanscher (1993). The authors of the fungal names are according to the Fungorum index (www.indexfungorum.org/AuthorsOfFungalNames.htm).

\section{Data analysis}

AM fungal composition was evaluated from the isolation frequency (IF), spore density, and species richness associated with each plant species. IF was expressed as the percentage of samples from which spores of a particular genus or species were isolated. Spore density (spores per $50 \mathrm{ml}$ air-dried soil) was calculated from direct counts of spores. Species richness was defined as the number of AM fungal species per soil sample (Koske, 1987). The correlation between percentage of root length colonized, intensity of infection and spore density was analyzed by linear regression analysis. Goodness of fit was assessed by simple correlation coefficients $(r)$ and degrees of freedom.

\section{Results}

\section{AM colonization}

Non-septate hyphae characteristic of AM fungi were present in $25(68 \%)$ of 37 plant species screened. The mean percentage of root length colonized was $21.34 \%$, ranging from 0 to $90 \%$. The mean intensity of root infection was $6.73 \%$, ranging from 0 to $50 \%$. Among the plant species, Amaranthus hybridus and Brassica rapa belonged to Amaranthaceae and Brassicaceae (families often considered to be non-mycorrhizal) respectively, were typically colonized by AM fungi. Twelve plant species belonging to 9 angiosperm families remained non-mycorrhizal (Table 1).

\section{AM structures}

AM fungal structures, i.e. vesicles and arbuscules were present only in $11 \%$ of the plant species. Majority of plant species (51\%) formed Paris-type and only $16 \%$ of plants formed Arum-type of colonization and in 12 plants the AM type could not be detected owing to the rare incidence of intercellular non-septate hyphae or vesicles in the roots.

\section{Composition of AM fungi in soil}

The average spore density of AM fungi was 43 spores per $50 \mathrm{ml}$ air-dried soil, ranging from 10 to 160 , and the average species richness was 2.4 species per sample, ranging from 1 to 5 (Table 1). There was no correlation among percentage root length colonized by AM fungi, intensity of infection $(r=0.923, P>0.05)$ and spore density $(r=0.311, P>0.05)$, as well as between intensity of infection and spore density $(r=0.237$, $P>0.05)$ (results not shown). 
Table 1. Arbuscular mycorrhizal (AM) association with roots and diversity in root region soils of common plants in Eritrea.Relative development of structures shown as: + present, not detected, ND not determined (Length AM root length \%, intensity intensity of root infection by AM \%, V vesicles, A arbuscules, type Arum, Paris, density spore density per 50 ml air-dried soil, number species number per soil sample)

\begin{tabular}{|c|c|c|c|c|c|c|c|c|}
\hline & Family & Length & Intensity & Vesicles & Arbuscules & Type & Density & Number \\
\hline \multicolumn{9}{|l|}{ Plant species } \\
\hline Acanthospermum hispidum DC. & Asteraceae & 10.50 & 1.05 & - & - & $\mathrm{P}$ & 30 & 2 \\
\hline Achyranthes aspera $\mathrm{L}$. & Amaranthaceae & 0.00 & 0.00 & - & - & ND & 15 & 2 \\
\hline Aerva javanica (Brum. F.) Schultes & Amaranthaceae & 0.00 & 0.00 & - & - & $\mathrm{ND}$ & 10 & 1 \\
\hline Amaranthus hybridus L. & Amaranthaceae & 65.00 & 32.50 & + & + & A & 25 & 2 \\
\hline Bidens biternata (Lour.) Merril \& Sherff & Asteraceae & 9.52 & 1.90 & - & - & $\mathrm{P}$ & 20 & 2 \\
\hline Brassica rapa $\mathrm{L}$. & Brassicaceae & 33.33 & 5.83 & - & - & $\mathrm{P}$ & 26 & 3 \\
\hline Calotropis procera (Ait.) Ait. f. & Asclepiadaceae & 0.00 & 0.00 & - & - & ND & 20 & 1 \\
\hline Chenopodium schraderianum Schultes & Chenopodiaceae & 0.00 & 0.00 & - & - & ND & 24 & 2 \\
\hline \multicolumn{9}{|l|}{ Commicarpus plumbagineus (Cav.) } \\
\hline Standley & Nyctaginaceae & 0.00 & 0.00 & - & - & $\mathrm{ND}$ & 95 & 3 \\
\hline Cosmos bipinnatus Cav. & Asteraceae & 26.66 & 4.66 & - & - & $\mathrm{P}$ & 10 & 2 \\
\hline Crotalaria sp. & Fabaceae & 15.38 & 2.30 & - & - & $\mathrm{P}$ & 60 & 1 \\
\hline Datura stramonium $\mathrm{L}$. & Solanaceae & 58.82 & 14.11 & - & - & $\mathrm{P}$ & 35 & 3 \\
\hline Echium plantagineum $\mathrm{L}$. & Boraginaceae & 70.00 & 32.00 & + & + & A & 55 & 2 \\
\hline Emex spinosa (L.) Campol. & Polygonaceae & 37.50 & 3.75 & - & - & $P$ & 75 & 1 \\
\hline Eruca sativa Mill. & Brassicaceae & 0.00 & 0.00 & - & - & ND & 45 & 2 \\
\hline Erucastrum arabicum Fisch. \& Mey. & Brassicaceae & 0.00 & 0.00 & - & - & $\mathrm{ND}$ & 62 & 2 \\
\hline Heliotropium cinerascens DC. & Boraginaceae & 33.33 & 5.55 & - & - & $\mathrm{P}$ & 160 & 5 \\
\hline Hypoestes forskaolii (Vahl.) R. Sch. & Acanthaceae & 35.00 & 7.50 & - & - & $P$ & 60 & 3 \\
\hline Leocas martinicensis (Jacq.) R. Br. & Lamiaceae & 28.57 & 5.00 & - & - & $\mathrm{P}$ & 35 & 3 \\
\hline Osteospermum vaillanthii (Decne) T. Nordl. & Asteraceae & 9.09 & 0.09 & - & - & $\mathrm{P}$ & 30 & 1 \\
\hline Pennisetum villosum Fresen. & Poaceae & 38.88 & 20.27 & - & - & A & 34 & 4 \\
\hline Pennisetum sphacelatum (Nees) Th. Dur. \& Schinz & Poaceae & 30.00 & 9.50 & - & - & A & 73 & 5 \\
\hline Plantago lanceolata $\mathrm{L}$. & Plantaginaceae & 0.00 & 0.00 & - & - & $\mathrm{ND}$ & 56 & 3 \\
\hline Prosopis juliflora (Sw.) DC. & Fabaceae & 10.00 & 2.00 & - & - & $\mathrm{P}$ & 19 & 2 \\
\hline Pulicaria crispa (Forssk.)Oliv. & Asteraceae & 10.00 & 1.00 & - & - & $\mathrm{P}$ & 26 & 2 \\
\hline Reichardia tingitana (L.) Roth & Asteraceae & 0.00 & 0.00 & - & - & ND & 30 & 1 \\
\hline Rumex nervosus Vahl. & Polygonaceae & 0.00 & 0.00 & - & - & $\mathrm{ND}$ & 15 & 1 \\
\hline Rumex nepalensis Spreng. & Polygonaceae & 90.90 & 50.00 & + & + & A & 85 & 4 \\
\hline Salvia shimperi Benth. & Lamiaceae & 5.00 & 0.50 & - & - & $P$ & 70 & 4 \\
\hline Schoenefeldia gracilis Kunth & Poaceae & 78.94 & 35.78 & + & + & A & 60 & 1 \\
\hline Scolymus maculatus L. & Asteraceae & 29.30 & 5.86 & - & - & $\mathrm{P}$ & 90 & 4 \\
\hline Senna italica Mill. & Fabaceae & 6.25 & 0.06 & - & - & $P$ & 32 & 3 \\
\hline Solanum dubium Fresen. & Solanaceae & 28.57 & 5.00 & - & - & $\mathrm{P}$ & 28 & 2 \\
\hline Solanum incanum L. & Solanaceae & 0.00 & 0.00 & - & - & $\mathrm{ND}$ & 21 & 2 \\
\hline Solanum nigrum $\mathrm{L}$. & Solanaceae & 22.22 & 2.22 & - & - & $P$ & 15 & 3 \\
\hline Tagetes minuta $\mathrm{L}$ & Asteraceae & 6.66 & 0.66 & - & - & $\mathrm{P}$ & 25 & 2 \\
\hline Xanthium strumatium $\mathrm{L}$. & Asteraceae & 0.00 & 0.00 & - & - & $\mathrm{ND}$ & 20 & 2 \\
\hline Average & - & 21.34 & 6.73 & - & - & - & 43 & 2.38 \\
\hline
\end{tabular}

The plant species sampled were associated with 18 described species and three undescribed morphotypes forming glomoid spores. The fungi represented five genera belonging to three families of Glomeromycota. The fungi most frequently found were Glomus spp. (12 described species and five undescribed morphotypes). Additionally, species of $A$. spinosa, D. celata, D. spurca, S. dipurpurescens, S. fulgida (Diversisporaceae) and Ar. trappei (Archeosporaceae) were isolated. The species most frequently co-occurring with roots of plants considered were G. mosseae (found in 
$42.31 \%$ of root region soils). G. claroideum (23.08\%), Ar. trappei (15.38\%), $G$. Constrictum, G. intraradices and G. irragulare (9.61\% each) (Table 2).

Table 2. Frequency of occurrence of the AM fungi found in the root region of common plants in Eritrea

\begin{tabular}{ll}
\hline Fungal species and morphotypes & $\begin{array}{l}\text { Frequency of occurrence } \\
(\%)\end{array}$ \\
\hline Acaulospora spinosa C. Walker \& Trappe & 1.92 \\
Archaeospora trappei (R.N. Ames \& Linderman) J.B. Morton & 15.38 \\
\& D. Redecker emend. Spain & \\
Diversispora celata C. Walker, Gamper \& A. Schüßler, & 3.85 \\
in Gamper, Walker \& Schüßler & \\
Diversispora spurca (C.M. Pfeiff., C. Walker \& Bloss) C. & 7.69 \\
Walker \& Schuessler & \\
Glomus aurantium Błaszk., Blanke, Renker \& Buscot & 1.92 \\
G. caledonium (T.H. Nicolson \& Gerd.) Trappe \& Gerd. & 1.92 \\
G. claroideum N.C. Schenck \& G.S. Sm. & 23.1 \\
G. clavisporum (Trappe) R.T. Almeida \& N.C. Schenck & 1.92 \\
G. constrictum Trappe & 9.61 \\
G. etunicatum W.N. Becker \& Gerd. & 5.77 \\
G. indicum Blaszk., Wubet \& Harikumar & 3.85 \\
G. intraradices N.C. Schenck \& G.S. Sm. & 9.61 \\
G. irregulare Błaszk., Wubet, Renker \& Buscot & 9.61 \\
G. macrocarpum Tul. \& C. Tul. & 1.92 \\
G. mosseae (T.H. Nicolson \& Gerd.) Gerd. \& Trappe & 42.31 \\
G. versiforme (P. Karsten) S.M. Berch & 3.85 \\
Glomus 178 & 3.85 \\
Glomus 212 & 1.92 \\
Glomus 213 & 1.92 \\
Scutellospora dipurpurescens J.B. Morton \& Koske & 1.92 \\
S. fulgida Koske \& C. Walker & 1.92 \\
\hline
\end{tabular}

\section{Discussion}

\section{AM status of plant species}

Our results, in general, confirm previous reports indicating that AM fungi are ubiquitous in terrestrial plant communities, associating with the majority of plant species (Smith and Read, 1997; Schüßler et al., 2001; Blaszkowski and Czerniawska, 2011) as $68 \%$ of the common plants of Eritrea screened in the present study were mycotrophic. Furthermore, the presence of intraradical non-septate mycelium, vesicles and arbuscules is considered elsewhere to be the evidence of colonization by AM fungi (Duckett and Ligrone, 1991; Gemma et al., 1992). As far as we are aware many reports of mycorrhiza in the present study are the first published reports of some of these plant species.

In general, the extent of mycotrophy in terms of percentage colonization by AM fungi and the intensity of root infection in common plants of Eritrea were comparatively low except in some plants where the colonization increased up to $91 \%$, for example,

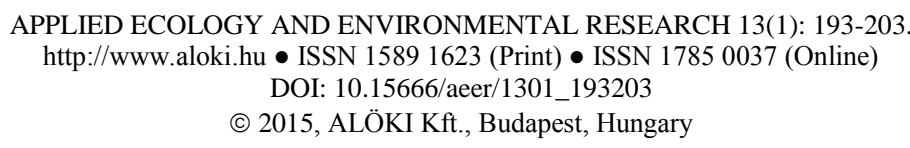


Rumex nepalensis (Fam. Polygonaceae). In the present study, the plant species belonging to non-mycotrophic families were found to be mycotrophic. This is in accordance with Norman et al. (1995) who also indicated that some of the representatives of the non-mycotrophic families viz. Amaranthaceae, Brassicaceae, Caryophyllaceae, Chenopodiaceae, Cyperaceae and Juncaceae could also form mycorrhizal associations. However, our findings contradict the earlier reports of Tao and Zhiwei (2005) and Shi et al. (2006) who reported that members of family Asclepiadaceae, Nictaginaceae and Plantaginaceae are responsive to arbuscular mycorrhizas, as none of the plant species examined in the present study showed mycorrhizal association.

Many researchers have reported mycorrhizal association in native plants of varied ecosystems e.g. Wubet et al. (2003) reported 11 indigenous trees in the dry Afromontane forests of Ethiopia as typically being arbuscular. Similar situations have been observed in other drought prone ecosystems (Mukerji and Kapoor, 1986; Stutz et al., 2000; Shi et al., 2006) where up to $89 \%$ of the plant species exhibited mycorrhizal association. On the contrary, only $79 \%$ of the plants were found to be mycorrhizal in the rain forest of south Cameroon (Onguene and Kuyper, 2001). Comparison of the AM fungal colonization rate and intensity of infection in roots from different ecosystems suggested that plants grown in the semi arid and arid habitats might be more dependent on AM fungi.

\section{AM colonization pattern}

The AM in the majority of common plants of Eritrea corresponds to the Paris-type, characterized by intracellular hyphal coils, and arbuscules originated as intercalary structures on the coils in contrast to the Arum-type with extensive intercellular hyphal growth and intracellular arbuscule formation described elsewhere (Yamato, 2004). Imhof and Weber (1997) suggested that Paris-type mycorrhizas are more advantageous to plants than Arum-type under extreme conditions. As the coiled hyphae could be a sign of major control by the plant over fungal development, they considered it to be more advanced than the Arum-type (Weber et al., 1995). The different AM structures may have specialized roles in transfer of inorganic nutrients and organic carbon between the symbiotic partners (Smith and Read, 1997; Smith and Smith, 1997), however paucity of information on the functions or relationship between the diversity and roles in varied ecosystems still exists.

\section{Spore density and its relationship with other fungal variables}

Our study reports a spore density up to 95 spores per $50 \mathrm{ml}$ air-dried soil, even in the root region soils of non mycorrhizal plants, presumably because of interwoven roots of other plants in the same field sample. Mycorrhizal plants may influence AM fungal spore number in the root region of non mycorrhizal plants (Zhao et al., 2001). It has been reported that both spore production and species richness of AM fungi are lower in arid climates than other ecosystems (Rose, 1981; Pond et al., 1984) and it decrease further as aridity increases (Stahl and Christensen, 1982; Stutz and Morton, 1996). The mean spore density of 43 spores per $50 \mathrm{ml}$ of soil in our study was lower than earlier reports from other ecosystem (Zhao et al., 2001; Li et al., 2004). However, our results agree with those from certain desert ecosystem such as the Mojave (Titus et al., 2002) and Negev (He et al., 2002) deserts. 
Contrasting to the report in other investigations (Muthukumar and Udaiyan, 2002), our results demonstrated no correlation between mycorrhizal variables such as percentage root length colonized by AM fungi, intensity of infection and spore density. The relationship between spore number, percentage colonization by AM fungi and intensity of infection is complicated as it is influenced by many environmental and biological factors (Smith and Smith, 1996; Liu and Wang, 2003). There are two possible explanations for our results: 1. the roots associated with AM fungi may have decayed prior to sampling, and 2. it is likely that some spores included in the counts were not viable, or were present in clusters functioning as a single infective propagule in field soil (Jasper et al., 1991; Jansa et al., 2002).

\section{AM diversity in soil}

The total number of AM fugal taxa (21) isolated in the present study coincides with the number reported by previous investigators in varied habitats. For example, 23 AM fungal taxa associated with 25 plant species were found in a grassland ecosystem using trap culture (Bever et al., 1996). Far fewer AM fungi (17 species) were found in samples from agricultural fields by both direct spore isolation and trap culture with different plants (Jansa et al., 2002) and even less in semiarid Sahelian areas of Africa (Dalpé et al., 2000) and hot arid ecosystems of southwest China (Tao and Zhiwei, 2005). It is likely that the site preference of AM species could be due to an interaction of factors pertaining to the host plants and to edaphic and climatic conditions (Brundrett, 1991). The present study reveals that Glomus is the dominant AM fungal genus which seems to be dominant in the root region of common plants of Eritrea. These findings are in agreement with the results of other researchers who reported the predominance of Glomus sp. in arid and semi-arid areas (e.g. Lamnot, 1982; Stutz et al., 2000; Chen et al., 2001; Pande and Tarafdar, 2004).

\section{Conclusion}

It can be concluded that the common plants of Eritrea host a variety of AM species in their roots and root region soils. The potential of these plants as alternate hosts of AM fungi and their role in the build up of indigenous AM inoculum in the soil for the benefit of cultivated plants have to be examined in detail.

Acknowledgements. The authors VSH, MKK and VDS thank Dr. Ghebrebrhan Ogubazghi, Academic Vice President, Eritrean Institute of Technology, Mai Nefhi, Eritrea for providing facilities and encouragement for the study.

\section{REFERENCES}

[1] Allen, M.F. (1991): The ecology of mycorrhizae - Cambridge University Press, Cambridge, UK

[2] Bever, J.D., Morton, J.B., Antonovics, J., Schultz, P.A. (1996): Host dependent sporulation and species diversity of arbuscular mycorrhizal fungi in a mown grassland. Journal of Ecology 84: 71-82.

[3] Bonfante, P., Genre, A. (2010): Mechanisms underlying beneficial plant-fungus interactions in mycorrhizal symbiosis. - Nature Communications 1: 48. 
[4] Brundrett, M. (1991): Mycorrhizas in natural ecosystems. - Advances in Ecological Research 21: 171-313.

[5] Brundrett, M., Kendrick, B. (1990): The roots and mycorrhizas of herbaceous woodland plants. II. Structural aspects of morphology. - New Phytologist 114: 469-479.

[6] Chen, X., Fang, Z., Tang, J. (2001): Investigation on host plants of vesicular-arbuscular mycorrhiza fungi (VAMF) within weed community in agricultural slope land in red soil area, southeastern China. - Biodiversity Science 9: 122-128.

[7] Dalpé, Y. (1993): Vesicular-arbuscular mycorrhiza. - In: Carter, M.R. (ed.) Soil sampling and methods of analysis, Lewis Publishers, Boca Raton FL, pp. 287-301.

[8] Dalpé, Y., Diop, T.A., Plenchette, C., Gueye, M. (2000): Glomales species associated with surface and deep rhizosphere of Faidherbia albida in Senegal. - Mycorrhiza 10: 125-129.

[9] Duckett, J.G., Ligrone, R. (1991): A light and electron microscopy study of the fungal endophyte of Lycopodium cernuum with observations on the gametophte-sporophyte junction. - Canadian Journal of Botany 70: 58-72.

[10] Edwards, S., Mesfin, T., Hedberg, I. (1995): Flora of Ethiopia and Eritrea; Volume 2, Part 2: Canellaceae to Euphorbiaceae. Addis Abeba, Ethiopia/Uppsala, Sweden.

[11] Edwards, S., Mesfin, T., Sebsebe, D., Hedberg, I. (2000): Flora of Ethiopia and Eritrea; Volume 2, Part 1: Magnoliaceae to Flacourtaceae. Addis Abeba, Ethiopia/Uppsala, Sweden

[12] Edwards, S., Sebsebe, D., Hedberg, I. (1997): Flora of Ethiopia and Eritrea; Volume 6: Hydrocaritaceae to Areceae. Addis Abeba, Ethiopia/Uppsala, Sweden

[13] Gallaud, I. (1905): Études sur les mycorrhizas endotrophes. - Rev Gén Bot 17: 5-48, 6683, 123-136, 223-239, 313-325, 425-433, 479-500

[14] Gemma, J.N., Koske, R.E., Flynn, T. (1992): Mycorrhizae in Hawaiian pteridophytes: occurrence and evolutionary significance. - American Journal of Botany 79: 843-852.

[15] Giri, B., Kapoor, R., Mukerji, K.G. (2007): Improved tolerance of Acacia nilotica to salt stress by arbuscular mycorrhiza, Glomus fasciculatum may be partly related to elevated $\mathrm{K} / \mathrm{Na}$ ratios in root and shoot tissues. - Microbial Ecology 54: 753-760.

[16] Harley, J.L., Smith, S.E. (1983): Mycorrhizal symbiosis - Academic, London.

[17] He, X.L., Mouratov, S., Steinberger, Y. (2002): Temporal and spatial dynamics of vesicular-arbuscular mycorrhizal fungi under the canopy of Zygophyllum dumosum Boiss. in the Negev Desert. - Journal of Arid Environment 52: 379-387.

[18] Hedberg, I., Edwards, S. (1989): Flora of Ethiopia and Eritrea; Volume 3: Pitosporaceae to Araliiaceae. Addis Abeba, Ethiopia/Uppsala, Sweden.

[19] Hedberg, I., Edwards, S. (1995): Flora of Ethiopia and Eritrea; Volume 7: Poaceae (Graminae). Addis Abeba, Ethiopia/Uppsala, Sweden.

[20] Hedberg, I., Edwards, S., Seleshi, N. (2003): Flora of Ethiopia and Eritrea; Volume 4: Part 1: Apiaceae to Dipsacaceae. Addis Abeba, Ethiopia/Uppsala, Sweden.

[21] Imhof, S., Weber, H.C. (1997): Root anatomy and mycotrophy (AM) of the achlorophyllous Voyria truncate (Standley) Standley \& Steyermark (Gentianiaceae). Botanica Acta 110: 127-134.

[22] Jansa, J., Mozafar, A., Anken, T., Ruh, R., Sanders, I.R., Frossard, E. (2002): Diversity and structure of AMF communities as affected by tillage in a temperate soil. Mycorrhiza 12: 225-234.

[23] Jasper, D.A., Abbott, L.K., Robson, A.D. (1991): The effect of soil disturbance on vesicular-arbuscular mycorrhizal fungi in soil from different vegetation types. - New Phytologist 118: 471-476.

[24] Komerup, A., Wanscher, J.H. (1993): Methuen hand book of colour, third ed, London, Eyre Methuen, London, UK.

[25] Koske, R.E. (1975): Endogone spores in Australia sand dunes. - Canadian Journal of Botany 53: 668-672. 
[26] Koske, R.E. (1987): Distribution of VA mycorrhizal fungi along a latitudinal temperature gradient. -Mycologia 79: 55-68.

[27] Koske, R.E., Gemma, J.N. (1989): A modified procedure for staining roots to detect VA mycorrhizas. - Mycological Research 92: 486-505.

[28] Koske, R.E., Gemma, J.N. (1996): Arbuscular mycorrhizal fungi in Hawaiian sand dunes: Island of Kaua'i. - Pacific Science 50: 36-45.

[29] Lamnot, B. (1982): Mechanisms for enhancing nutrient uptake in plants, with special reference to Mediterranean South Africa and Western Australia. - Botanical Review 48: 597-689.

[30] Li, T., Li, J.P., Zhao, Z.W. (2004): Arbuscular mycorrhizas in a valley-type savanna in southwest China. - Mycorrhiza 14: 323-327.

[31] Liu, R.J, Wang, F.Y. (2003): Selection of appropriate host plants used in trap culture of arbuscular mycorrhizal fungi. - Mycorrhiza 13: 123-127.

[32] Mc Gee, P.A. (1989): Variation in propagule numbers of vesicular arbuscular mycorrhizal fungi in a semi-arid soil. - Mycological Research 92: 28-33.

[33] Mukerji, K.G., Kapoor, A. (1986): Occurrence and importance of vesicular-arbuscular mycorrhizal fungi in semiarid regions of India. - Forest Ecology and Management 18: 117-126.

[34] Muthukumar, T., Udaiyan, K. (2002): Arbuscular mycorrhizas in cycads of southern India. - Mycorrhiza 12: 213-217.

[35] Norman, M.J.T., Pearson, C.J., Searle, P.G.E. (1995): The ecology of tropical food crops - Cambridge University Press, Cambridge.

[36] Omar, M.B., Bollan, L., Heather, W.A. (1979): A permanent mounting medium for fungi. - Bulletin of British Mycological Society 13: 31-32.

[37] Onguene, N.A., Kuyper, T.W. (2001): Mycorrhizal associations in the rain forest of south Cameroon. - Forest Ecology and Management 140: 277-287.

[38] Pande, M., Tarafdar, J.C. (2004): Arbuscular mycorrhizal fungal diversity in neembased agroforestry systems in Rajasthan. - Applied Soil Ecology 26: 233-241.

[39] Plenchette, C., Morel, C. (1996): External phosphorus requirements of mycorrhizal and non-mycorrhizal barley and soybean plants. - Biology and Fertility of Soils 21: 303308.

[40] Pond, E.C., Menge, J.A., Jarrel, W.M. (1984): Improved growth of tomato in salinized soil by vesicular-arbuscular mycorrhizal fungi collected from saline soils. - Mycologia 76: 74-84.

[41] Rose, S.L. (1981): Vesicular-arbuscular mycorrhizal associations of some desert plants of Baja California. - Canadian Journal of Botany 59: 1056-1060.

[42] Schüßler, A., Schwarzott, D., Walker, C. (2001): A new fungal phylum, the Glomeromycota: phylogeny and evolution. - Mycological Research 105: 1413-1421.

[43] Shi, Z.Y., Feng, G., Christie, P., Li, X.L. (2006): Arbuscular mycorrhizal status of spring ephemerals in the desert ecosystem of Junggar Basin, China. - Mycorrhiza 16: 269-275.

[44] Smith, F.A., Smith, S.E. (1996): Mutualism and parasitism: diversity in function and structure in the "arbuscular" (VA) mycorrhizal symbiosis. - Advances in Botanical Research 22: 1-43.

[45] Smith, F.A., Smith, S.E. (1997): Structural diversity in (vesicular-) arbuscular mycorrhizal symbiosis. - New Phytologist 137: 373-388.

[46] Smith, S.E., Jakobsen, I., Grønlund, M., Smith, F.A. (2011): Roles of arbuscular mycorrhizas in plant phosphorus nutrition: interactions between pathways of phosphorus uptake in arbuscular mycorrhizal roots have important implications for understanding and manipulating plant phosphorus acquisition. - Plant Physiology 156: 1950-1057.

[47] Smith, S.E., Read, D.J. (1997): Mycorrhizal symbiosis, second ed - Academic Press, San Diego, CA. 
[48] Stahl, P.D., Christensen, M. (1982): Mycorrhizal fungi associated with Bouteloua and Agropyron in Wyoming sagebrush-grassland. - Mycologia 74: 877-885.

[49] Stürmer, S.L., Morton, J.B. (1997): Developmental patterns defining morphological characters in spores of four species in Glomus. - Mycologia 89: 72-81.

[50] Stutz, J.C., Copeman, R., Martin, C.A., Morton, J.B. (2000): Patterns of species composition and distribution of arbuscular mycorrhizal fungi in arid regions of southwestern North America and Namibia, Africa. - Canadian Journal of Botany 78: 237-245.

[51] Stutz, J.C., Morton, J.B. (1996): Successive pot cultures reveal high species richness of arbuscular endomycorrhizal fungi in arid ecosystems. - Canadian Journal of Botany 74: 1883-1889.

[52] Tao Li., Zhiwei, Z. (2005): Arbuscular mycorrhizas in a hot and arid ecosystem in southwest China. - Applied Soil Ecology 29: 135-141.

[53] Tisdall, J.M., Oades, J.M. (1982): Organic matter and water stable aggregates in soils. Journal of Soil Science 33: 141-163.

[54] Titus, J.H., Titus, P.J., Nowak, R.S., Smith, S.D. (2002): Arbuscular mycorrhizae of Mojave Desert plants.- West North American Naturalist 62: 327-334.

[55] Walker, C. (1983): Taxonomic concepts in the Endogonaceae spore wall characteristics in species descriptions. - Mycotaxon 18: 443-455.

[56] Weber, H.C., Klahr, A., Manon-Heimbuch, M. (1995) Anatomical structures of the VA mycorrhiza in the Apocynaceae (Gentianales). - Botanica Acta 108: 525-534.

[57] Wubet, T., Kottke, I., Teketay, D., Oberwinkler, F. (2003): Mycorrhizal status of indigenous trees in dry Afromontane forests of Ethiopia. - Forest Ecology and Management 179: 387-399.

[58] Yamato, M. (2004): Morphological types of arbuscular mycorrhizal fungi in roots of weeds on vacant land. - Mycorrhiza 14: 127-131.

[59] Zhao, Z.W., Xia, Y.M., Qin, X.Z., Li, X.W., Cheng, L.Z., Sha, T., Wang, G.H. (2001): Arbuscular mycorrhizal status of plants and the spore density of arbuscular mycorrhizal fungi in the tropical rain forest of Xishuangbanna, southwest China. - Mycorrhiza 11:159-162. 